\title{
Anaerobic Treatment of Rubber Latex Processing Effluent for Energy Production and Pollution Abatement
}

\author{
A. S. Megha ${ }^{1 *}$, P. Shaji James ${ }^{2}$ and Joejoe L. Bovas ${ }^{3}$ \\ ${ }^{1}$ KelappajiCollege of Agricultural Engineering \& Technology (KCAET), Tavanur, Kerala, \\ ${ }^{2}$ Kerala Agricultural University, Thrissur, India \\ ${ }^{3}$ Gandhigram Rural Institute, Gandhigram, Dindigul District, Tamil Nadu, India \\ *Corresponding author
}

\section{A B S T R A C T}

\section{Keywords}

Rubber Latex Processing Effluent, Anaerobic

Article Info

Accepted:

12 October 2020

Available Online:

10 November 2020
Rubber latex processing plants generally produce large quantity of effluents which contains high amount of degradable organic matter characterised by high BOD, COD and TS. The rubber latex processing effluent (RLPE) is often not properly treated in many rubber latex processing plants before discharged to land. This may affect the local environment resulting in adverse effects on public health. Hence adoption of a suitable and affordable technology for waste stabilization and energy generation is needed. In order to develop a suitable anaerobic bioreactor, the biomethanation characteristics should be known and hence such a study was taken up. Even though RLPE was acidic it was found that RLPE could be subjected to biomethanation using cow dung slurry as inoculum. Even at a lower RLPE: inoculum ratio, the system could be started up and yield appreciable levels of biogas coupled with - per cent TS reduction. The use of formic acid for latex coagulation is a better option as the effluent treatment process is trouble free and facilitates anaerobic digestion to produce methane rich biogas to be used to dry rubber sheets

\section{Introduction}

Among the plantation crops, rubber holds a prominent position in Kerala and is a main source of livelihood for many farmers of the state (Karunakaran and Vijayan, 2020). Natural rubber is used in diverse applications owing to its many desirable qualities including large stretch ratio and resilience (Chauhan et al., 2020), toughness, minimum hysteresis, elasticity and durability (Jansomboon et al., 2020). Hence, they are of high demand in the automobile industry, preparation of surgical rubber goods and many other goods which have become a daily necessity for people (Guan et al., 2020). Natural rubber consists mainly of cis-1,4polyisoprene, protein and fatty acids (Azadi $e t$ $a l ., 2020)$. It is mainly harvested by tapping the rubber trees and obtained in the form of a milky colloidal suspension called rubber latex (Kang et al., 2020). Tapping is the process of making incisions manually on the bark of rubber trees using special knives (Kamil et al., 2020). The collected latex mixed with water is coagulated under control conditions using formic acid. The coagulated latex is then allowed to set in a dish. Once the latex is 
fully set the excess water is squeezed out using pressing rollers so as to convert it into thin sheets. These rubber sheets are then dried by open sun drying or in biomass fired drying chambers, often called 'smoke chambers' (Nhu Hien et al., 2017). The important primary products of the rubber processing industry includes concentrated latex, block rubber and ribbed smoked sheet rubber (Jawjit et al., 2010).

In the light of net zero carbon footprint the natural rubber production is increasing (Tanikawa et al., 2020) but at the same time the rubber latex processing effluents (RLPE) released is causing water, soil and air pollution (Nhu Hien et al., (2017) and Brooks et al., (2017)). The fact that $6-7 \mathrm{~m}^{3}$ of water is required for processing one tonne of concentrated latex (Jawjit et al., 2013) explains the quantity of effluent disposed by each rubber processing industry. It is estimated that by 2024 an additional plantation of 4.3-8.5 million ha is needed to meet the growing industrial demand (WarrenThomas et al., 2015). This tells the urgency of solving the environmental problems that can be raised by RLPE. The latex processing effluent mainly contains BOD, $\mathrm{COD}, \mathrm{NH}_{3}-\mathrm{N}$, organic nitrogen and phosphate (Jawjit and Liengcharernsit, 2010), in complex mixture form with varying compositions (Arimoro, 2009). The chemicals such as Ammonia and Diammonium phosphate used for latex preservation causes human toxicity and eutrophication respectively (Jawjit et al., 2013) and the $\mathrm{H}_{2} \mathrm{~S}$ present in RLPE can make river water unsafe for drinking up to several hundred miles downstream from the disposal point (Martinez-Hernandez and Hernandez, 2018). In addition these chemicals on open water bodies causes huge depletion of dissolved oxygen (Atagana et al., 1999; Brooks et al., 2017) thus affecting the related ecosystem components, agricultural activities and human health (Martinez-Hernandez and
Hernandez, 2018). Larger processing centers have treatment facilities, but many of the small and medium rubber latex processing units let out these effluents to open lands or water bodies without proper treatment. On open treatment, the degradation of volatile fatty acids can produce greenhouse gases whereas proper bio-methanation can produce energy (Tanikawa, et al., 2020). This emphasizes the need for engineering a sustainable and environment friendly system which can last for a long-term for treating RLPE (Fox et al., 2014).

Kerala state of India, known as 'God's own country' in the world tourism scenario is famous for its natural beauty and earns a significant share of its GDP from tourism (Fenn et al., 2020). Kerala is ranked first in India for annual rubber production of 490460 tonnes in 2018-2019 (MCI, 2019), and there is a serious concern on the environmental problem due to discharge of untreated RLPE. In addition to the pollution due to RLPE, the drying of rubber sheets in biomass fired dryers called 'smoke chambers' are also causing air pollution. If the RLPE is subjected to anaerobic treatment, the pollution due to effluent discharge can be significantly controlled and the biogas generated can be utilized to dry rubber sheets so as to replace the biomass which is burned in inefficient smoke chambers. Hence an investigation was taken up for studying the possibilities of anaerobic treatment of RLPE with the intension of energy production in the form of a methane rich biogas.

\section{Materials and Methods}

To understand the basic characteristics of RLPE relevant for anaerobic digestion the $\mathrm{pH}$ value, Total Solid content (TS), Volatile Solid content (VS), Biochemical oxygen demand (BOD) and Chemical oxygen demand (COD) were observed as per the procedure detailed 
by (APHA, 2017).The pH of RLPE samples were measured using a digital $\mathrm{pH}$ meter MKVI with $\mathrm{pH}$ range of $0-14 \mathrm{pH}$ and a resolution of 0.01. Oven drying method was adopted for determining TS and was expressed in $\mathrm{mg} \mathrm{L}^{-1}$ dry basis. To obtain VS of the sample the residue from TS was ignited in a muffle furnace at $550{ }^{\circ} \mathrm{C}$ for 15 to 20 minutes. The difference between TS and ash obtained was taken as VS $\left(\mathrm{mg} \mathrm{L}^{-1}\right)$. Similarly, five-day BOD and COD was determined using standard procedure outlined by APHA (2017).

In order to understand the biomethanation characteristics and possibilities for anaerobic digestion of RLPE a batch anaerobic digestion study with 4 treatments replicated thrice was conducted (Fig. 1and 2). Water displacement method was adopted to measure the daily gas production from experimental digesters. Five litre capacity plastic digesters connected with 3 litre capacity graduated cylinders used as water displacement meters were set up for the experiment as shown in Fig 1. Cow dung was used as inoculum for the 3 treatments whereas effluent collected from a conventional biogas plant was used for the $4^{\text {th }}$ treatment. Daily biogas production was measured for 75 days. The $\mathrm{pH}$ values and TS were noted before and after digestion. The four treatments for the experiment were as below:

T0 - Fresh Cow dung : water (1:1)

$\mathrm{T} 1$-Cow dung mixed with RLPE in the ratio $(1: 1)$

T2 - Cow dung mixed with water and RLPE $(1: 1: 2)$

T3 - Effluent from conventional biogas plant: RLPE (1:1)

\section{Results and Discussion}

The results of the investigations on the characteristics of rubber latex processing effluent (RLPE) and the batch anaerobic digestion of RLPE are presented and discussed in the sub sections below.

\section{Characteristics of RLPE}

The results of the analyses done for various Physico-chemical characteristics of RLPE samples are given in Table 1. RLPE was very dilute waste water with TS and BOD, in the ranges of 9281-12892 mg/L and $2040-3106$ $\mathrm{mg} / \mathrm{L}$, respectively. The $\mathrm{pH}$ was in the acidic range and was observed to vary in the range between 5.1 and 6.1 during the period of investigation. These results are comparable with the values obtained by Ramanan and Vijayan (2015) and Brooks (2017). Ramanan and Vijayan (2015) reported TS of 9700 $\mathrm{mg} / \mathrm{L}, \mathrm{BOD}$ of $4300 \mathrm{mg} / \mathrm{L}$ and a $\mathrm{pH}$ of $5.7 \pm$ 0.30 for RLPE. In a survey conducted by Chaiprapat and Sdoodee (2007) on 20 rubber processing factories in Pathalung and Songkhla provinces of Thailand, it was found that the BOD of RLPE ranged between 680$7384 \mathrm{mg} / \mathrm{L}$ and TS between 715-13,813 mg/L where as RLPE tested by Promnuan et al., (2019) had a pH of 5 and TS of $4619 \mathrm{mg} / \mathrm{L}$. The RLPE used for the present study also had characteristics in the range of values in these reports.

The Volatile Solid content was found to be $2356 \mathrm{mg} / \mathrm{L}$ and this value was also similar to the reported value of $1845 \mathrm{mg} / \mathrm{L}$ by Jacob (1994) and $2260 \mathrm{mg} / \mathrm{L}$ by Promnuan et al., (2019) for rubber sheet processing effluent. Bovas and James (2010) reported a BOD of $3599 \mathrm{mg} / \mathrm{L}$ and TS of $3090 \mathrm{mg} / \mathrm{L}$ for rice mill effluent, which could be successfully subjected to anaerobic treatment. The COD of RLPE were observed to be $5856 \mathrm{mg} / \mathrm{L}$ and was higher than rice mill effluent. BOD: COD ratio of 0.44 obtained in this study showed good biodegradability and possibility for anaerobic digestion. Bovas and James (2010) observed a BOD: COD ratio of 0.88 for rice mill effluent, whereas James and Kamaraj 
(2009) reported a ratio of 0.57 for sago factory effluent. In both these cases good biodegradability was achieved by them. Promnuan et al., (2019) reported a COD of $6667 \mathrm{mg} / \mathrm{L}$ and Chaiprapat and Sdoodee (2007) reported a COD range between 1118 and $11,105 \mathrm{mg} / \mathrm{L}$ for RLPE, which were supportive of the values obtained in the present study. This wide range variation of values reported by Chaiprapat and Sdoodee (2007) can be explained by the result of Brooks (2017), that the characteristics of RLPE depends on the quality of the raw material used and processing process adopted by the industry.

\section{Batch anaerobic digestion of RLPE}

Most organic effluents are easily biodegraded. Possibilities for biodegradation of RLPE were important to evolve a proper anaerobic treatment protocol for anaerobic digestion in a high rate bioreactor. Atagana et al., (1999) reported RLPE had the ability to support microbial population.

Table.1 Characteristics of RPLE

\begin{tabular}{|l|l|l|}
\hline Sl. No. & \multicolumn{1}{|c|}{ Parameters } & \multicolumn{1}{|c|}{ Mean value } \\
\hline $\mathbf{1}$ & Total solids, $\mathrm{mg} / \mathrm{L}$ & 11086.7 \\
\hline $\mathbf{2}$ & Volatile solids, $\mathrm{mg} / \mathrm{L}$ & 2356 \\
\hline $\mathbf{3}$ & Biochemical Oxygen Demand, $\mathrm{mg} / \mathrm{L}$ & 2572.9 \\
\hline $\mathbf{4}$ & Chemical Oxygen Demand, $\mathrm{mg} / \mathrm{L}$ & 5856 \\
\hline $\mathbf{5}$ & $\mathrm{pH}$ & 5.6 \\
\hline $\mathbf{6}$ & BOD : COD ratio & 0.44 \\
\hline
\end{tabular}

Table.2 Parameters of batch digestion study

\begin{tabular}{|c|c|c|c|c|c|c|}
\hline \multirow{2}{*}{$\begin{array}{c}\text { SI. } \\
\text { No. }\end{array}$} & Treatments & \multicolumn{2}{|c|}{ Total solids (TS), mg/L } & TS Reduction & \multicolumn{2}{|c|}{$\mathbf{p H}$} \\
\hline & & Initial & Final & $(\%)$ & Initial & Final \\
\hline $\mathbf{1}$ & T0 & 27382 & 11920 & 56.46 & 7 & 8.1 \\
\hline $\mathbf{2}$ & T1 & 15520 & 6600 & 57.47 & 6.7 & 7.8 \\
\hline $\mathbf{3}$ & T2 & 19524 & 9550 & 51.08 & 6.9 & 7.8 \\
\hline $\mathbf{4}$ & T3 & 6527 & 4527 & 30.63 & 7 & 8.2 \\
\hline
\end{tabular}

Fig.1 Experimental set up for batch anaerobic digestion

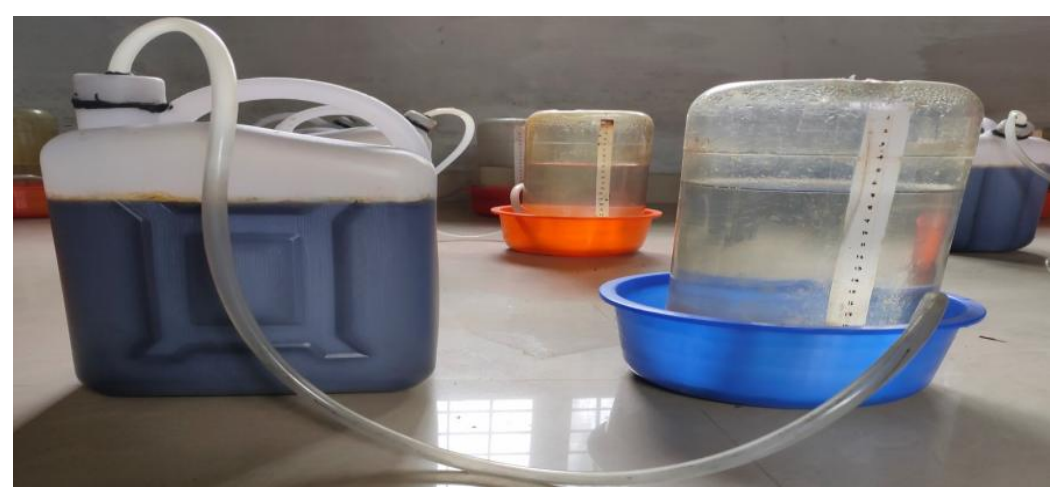


Fig.2 Arrangement of experimental digesters for batch anaerobic digestion

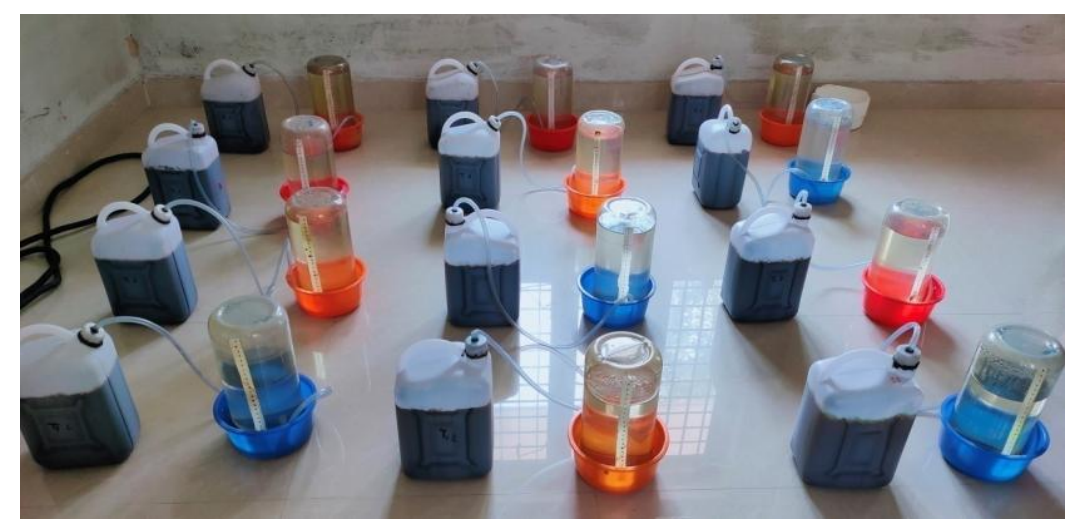

Fig.3 Daily biogas production in batch anaerobic digestion study

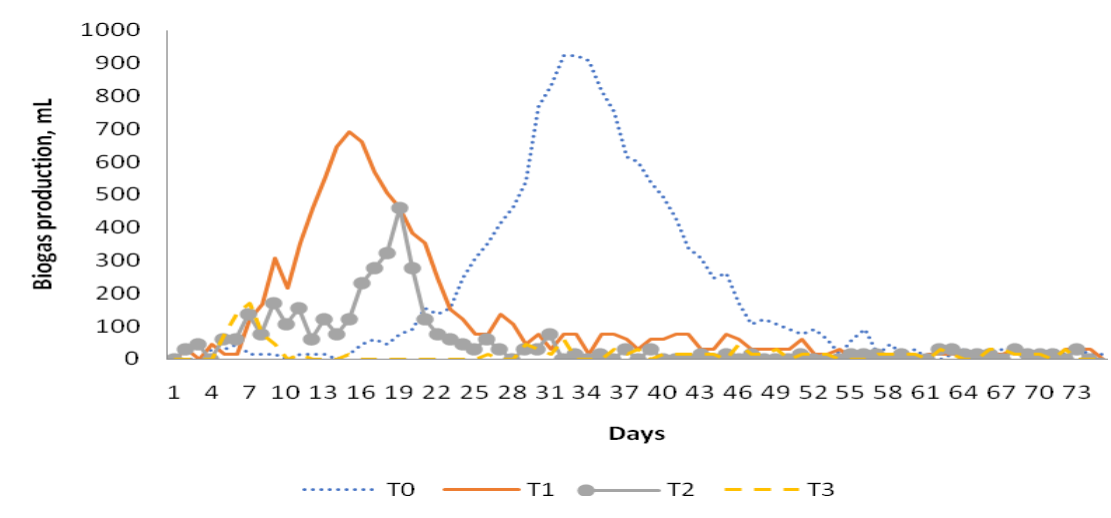

Fig.4 Cumulative biogas production in batch study

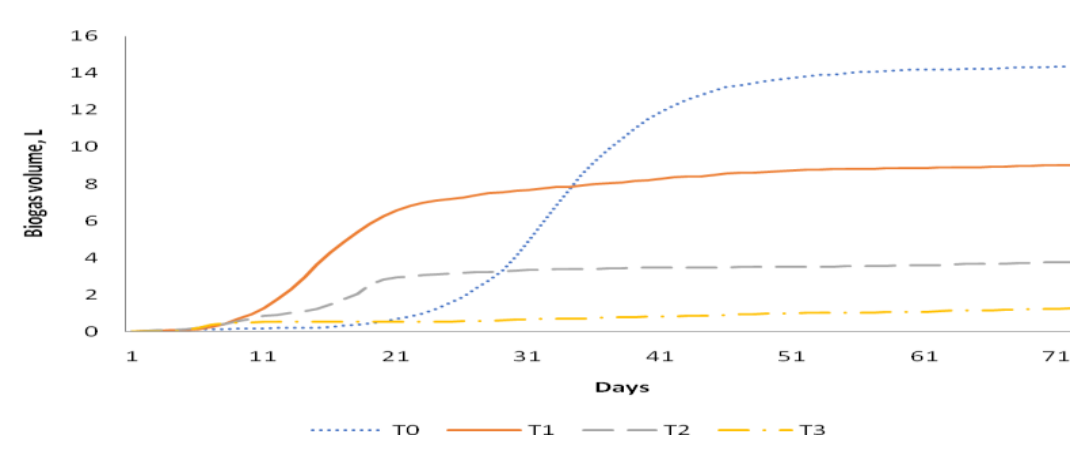

From Table 2 it can be seen that T0, the control treatment exhibited a TS reduction of $56.46 \%$. Similar TS reductions of 57.47 and 51.08 per cent were obtained for $\mathrm{T} 1$ and $\mathrm{T} 2$ respectively. Bovas and James (2010) observed $60.2 \%$ TS reduction for a batch digestion study of rice mill effluent which was conducted for duration of 135 days. TS reduction in $\mathrm{T} 3$ was $30.63 \%$ which was lower than other treatments. The result from $\mathrm{T} 3$ showed that the inoculum used in $\mathrm{T} 3$ was inferior to ordinary cow dung slurry to be used as inoculum.

The $\mathrm{pH}$ in all treatments was observed to be raised at the end of digestion. The final $\mathrm{pH}$ of 
all the treatments reached the values in the range 7.8-8.2. A similar trend was observed by Ramanan and Vijayan (2015) also. From Fig 3 it can be seen that $\mathrm{T} 0$ had slow gas production in the beginning and picked up gas production after two weeks. The peak gas production of $923 \mathrm{~mL}$ occurred on $32^{\text {nd }}$ day and started declining after $34^{\text {th }}$ day. Up to $49^{\text {th }}$ day gas production was good, later biogas production reduced to below $100 \mathrm{~mL}$. This indicated that a Hydraulic Retention Time (HRT) of 50 days will be suitable for conventional anaerobic systems for energy production from cow dung in similar climatic conditions.

Treatment T3, inoculated with effluent from biogas plant did not exhibit gas production after the first week and the daily gas production remained very low throughout the remaining period of the experiment which lasted for 75 days. It can be inferred that effluent from existing anaerobic systems should be used as inoculum only after ascertaining its methanogenic capacity. Treatment T1, mixture of cow dung and RLPE (1:1), showed maximum gas production of $690 \mathrm{~mL}$ on $15^{\text {th }}$ day and declined to below $100 \mathrm{ml}$ after $24^{\text {th }}$ day. T2, mixture of cow dung, water and RLPE (1:1:2), obtained peak gas production of 460 $\mathrm{mL}$ on $19^{\text {th }}$ day and rapidly declined to very low levels. This indicated that 25-day HRT can be recommended for conventional anaerobic systems for the treatment and energy production of RLPE. During the study both $\mathrm{T} 1$ and $\mathrm{T} 2$ showed maximum gas production within 3 weeks and thereafter decreased. The treatment T3, obtained 160 $\mathrm{mL}$ of daily gas production on $8^{\text {th }}$ day which was the maximum daily gas production in T3. The difference of biogas production between $\mathrm{T} 1$ and $\mathrm{T} 2$ was due to the change in solid contents. T0 and T1 were different not only by the TS content but also on the ratio of partially soluble and insoluble compounds in cow dung compared to more soluble organics in RLPE.

The cumulative biogas production from different treatments is shown in Fig. 4. The control treatment had more cumulative biogas production of $14.43 \mathrm{~L}$. Total gas production in T1, T2 and T3 are 9.07 L, 3.80 L and 1.26 L, respectively. Biogas productivity of 3.60 , 2.26, 0.95 and $0.315 \mathrm{~L} / \mathrm{L}$ was achieved for the treatments $\mathrm{T} 0, \mathrm{~T} 1, \mathrm{~T} 2$ and $\mathrm{T} 3$, respectively. These differences in cumulative biogas production are due to the difference of total solids in the treatments.

This study concluded that RLPE could be subjected to biomethanation and cow dung can be used as inoculum. Even at a lower inoculum ratio the system could be started up yielding substantial amount of biogas coupled with good TS reduction. Treatment T3 proved that if effluent from an existing biogas plant is used as inoculum, it should be ascertained that the system is functional with active microbial population.

Chen et al., (2008) was of the view that ammonia concentrations in the range between $1.7-14 \mathrm{~g} / \mathrm{L}$ can partly inhibit methanogenesis. Nguyen and Luong (2012) was of the view that ammonia present in RLPE affects its biodegradation, while Jariyaboon et al., (2015) found that RLPE had $9 \mathrm{~g} / \mathrm{L}$ of ammonia nitrogen and it did not seriously affect the fermentation activity but $\mathrm{H}_{2} \mathrm{SO}_{4}$ used for coagulating the skim latex increased the sulfate concentration in the RLPE and that inhibited the methanogenic activity. Rahman et al., (2019) also had a similar opinion with regard to sulfate concentration as the result of using $\mathrm{H}_{2} \mathrm{SO}_{4}$ and found that it resulted in increased levels of $\mathrm{H}_{2} \mathrm{~S}$ in the biogas produced. Promnuan and O-Thong (2017) suggested the use of sulphate reducing bacteria to remove sulfate before anaerobic treatment. Jariyaboon et al., (2015) proposed 
a two-stage system with acidogenic phase in the first stage and methanogenic phase in the second stage. They were of the view that RLPE cannot be properly digested using a single stage digester. But the present study was taken up in a latex processing plant where only formic acid was used for coagulation of latex. Hence it can be inferred that the use of inorganic acids like sulphuric acid for rubber latex processing may be discouraged.

$\mathrm{Xu}$ et al., (2013) studied the effect of inoculum obtained from anaerobic digesters using municipal sewage, food waste and dairy waste in digesting corn stover using a batch digester. It was found that corn stover inoculated with dairy waste in the ratio $1: 2$ gave the best results. Neves et al., (2004) found that inoculums with higher specific methanogenic activity can give better methane yields and lesser variation on increasing the feed inoculum ratio. The results from the present study shows that RLPE from latex coagulated with formic acid can be subjected to biomethanation in a better way if inoculated with cow dung slurry. This indicated that cow dung as inoculum had good specific methanogenic activity. Sulphate reducing bacterial consortium may be required only if the latex is coagulated with inorganic acids like $\mathrm{H}_{2} \mathrm{SO}_{4}$. It was also observed that small amounts of ammonia will not affect anaerobic digestion considerably. This result obtained in the study is also supported by the findings of Jariyaboon et al., (2015). James and Kamaraj (2002) has described various anaerobic high rate systems for organic effluent treatment. Many previous studies confirm the possibility of anaerobic high rate bioreactors for the treatment and energy conversion of organic effluents (Najafpour et al., (2006), Elangovan and Philip (2009), Bovas and James (2010), Young et al., (2012), Kim et al., (2017), Ittisupornrat et al., (2019) and Rahman et al., (2019)).
Hence studies on the use of high rate anaerobic systems for RLPE may be taken up so as to reduce the HRT further and make the system cost effective.

From the present study it could be concluded that RLPE could be subjected to biomethanation and cow dung slurry can be used as inoculum. Even at a lower inoculums: RLPE ratio, system could be started up yielding substantial amount of biogas coupled with good TS reduction. Further investigations are required to test the possibilities for high rate anaerobic treatment of RLPE. The use of formic acid for latex coagulation is a better option as the effluent treatment process is trouble free and facilitates anaerobic digestion to produce methane rich biogas to be used to dry rubber sheets.

\section{References}

APHA. (2017). Standard methods for the examination of water and wastewater. American Public Health Association, Washington.

Arimoro, F. O. (2009). Impact of rubber effluent discharges on the water quality and macroinvertebrate community assemblages in a forest stream in the Niger Delta. Chemosphere, 77, 440449.

https://doi.org/10.1016/j.chemosphere.2 009.06.031

Atagana, H. I., Ejechi, B. O., and Ogodu, M. I. (1999). Bacteria associated with degradation of wastes from rubber processing industry. Environmental Monitoring and Assessment, 59, 145154.

https://doi.org/10.1023/A:10061792071 18

Azadi, S., Bagheri, H., Mohammad Parast, B., and Ghorbani-Marghashi, M. (2020). Natural rubber identification and characterization in Euphorbia 
macroclada. Physiology and Molecular Biology of Plants, 26, 2047-2052. https://doi.org/10.1007/s12298-02000880-5

Bovas, J. J. L., and James, P. S. (2010). Development of a Hybrid Anaerobic Bioreactor for Treatment and Energy Conversion of Rice Mill Effluent. Proceedings of 22nd Kerala Science Congress, 516-517.

Brooks, A., Iyakndue, M., Unimke, A., and Agbo, B. (2017). Rubber Effluent BioAnalyses and Its Impacts on the Microbial Community Structure of the Soil in Calabar, Nigeria. Asian Journal of Environment and Ecology, 4(3), 1-9. https://doi.org/10.9734/ajee/2017/35292

Chaiprapat, S., and Sdoodee, S. (2007). Effects of wastewater recycling from natural rubber smoked sheet production on economic crops in southern Thailand. Resources, Conservation and Recycling, 51, 577-590. https://doi.org/10.1016/j.resconrec.2006 .11 .003

Chauhan, P., Kumar, A., and Kumar, V. (2020). Rubber Technology. International Journal For Technological Research In Engineering, 7(9), 6830-6831. www.ijtre.com

Chen, Y., Cheng, J. J., and Creamer, K. S. (2008). Inhibition of anaerobic digestion process: A review. Bioresource Technology, 99, 40444064.

https://doi.org/10.1016/j.biortech.2007. 01.057

Elangovan, R., and Philip, L. (2009). Performance evaluation of various bioreactors for the removal of $\mathrm{Cr}(\mathrm{VI})$ and organic matter from industrial effluent. Biochemical Engineering Journal, 44, 174-186. https://doi.org/10.1016/j.bej.2008.11.01 4
Fenn, J., Nair, G., and George, S. (2020). What is it to be a Transgender in God ' s Own Country. Global Journal of Medical, Pharmaceutical, and Biomedical Update Case, 15(3), 1-3. https://doi.org/10.25259/GJMPBU

Fox, J. M., Castella, J. C., Ziegler, A. D., and Westley, S. B. (2014). Rubber plantations expand in mountainous Southeast Asia: What are the consequences for the environment? Asia Pacific Issues, 114. http://hdl.handle.net/10125/33109

Guan, J., Zhao, F., Gu, T., Liu, H., Luo, M. C., and Liao, S. (2020). Role of endogenous glucose on natural rubber molecular chains and natural network architecture based on biological action and chelation. In Polymer (Vol. 202). Elsevier Ltd. https://doi.org/10.1016/j.polymer.2020. 122752

Ittisupornrat, S., Phihusut, D., Kitkaew, D., Sangkarak, S., and Phetrak, A. (2019). Performance of dissolved organic matter removal from membrane bioreactor effluent by magnetic powdered activated carbon. Journal of Environmental Management, 248, 109314.

https://doi.org/10.1016/j.jenvman.2019. 109314

Jacob, M. 1994. Characterization of wastes from natural rubber and rubber wood processing industries and their utilization for biomethanation. Doctoral thesis, Cochin University of Science and Technology, Cochin, 247p.

James, P. S. and Kamaraj, S. 2002. Immobilised cell anaerobic bioreactors from anaerobic bioreactors for energy production from agro-industrial waste waters - An introduction. Bioenergy News. 6 (3): 10-15.

James, P. S., and Kamaraj, S. (2009). Performance of Up-flow Anaerobic 
Hybrid Reactors for pollution control and energy production from Cassava Starch Factory Effluent (CSFE). Journal of Tuber Crops, 35(1), 69-77. Jansomboon, W., Prapainainar, P., Loykulnant, S., Kongkachuichay, P., Dittanet, P., Kumnorkaew, P., Li, Z., Kinloch, I., and Young, R. J. (2020). Raman Spectroscopic Study of Reinforcement Mechanisms of Electron Beam Radiation Crosslinking of Natural Rubber Composites Filled with Graphene and Silica/Graphene Mixture Prepared by Latex Mixing. Composites Part C: Open Access, 3, 100049. https://doi.org/10.1016/j.jcomc.2020.10 0049

Jawjit, S., and Liengcharernsit, W. (2010). Anaerobic treatment of concentrated latex processing wastewater in twostage upflow anaerobic sludge blanket. Canadian Journal of Civil Engineering, 37, 805-813. https://doi.org/10.1139/L10-029

Jawjit, W., Kroeze, C., and Rattanapan, S. (2010). Greenhouse gas emissions from rubber industry in Thailand. Journal of Cleaner Production, 18, 403-411. https://doi.org/10.1016/j.jclepro.2009.1 2.003

Jawjit, W., Pavasant, P., and Kroeze, C. (2013). Evaluating environmental performance of concentrated latex production in Thailand. Journal of Cleaner Production, 98, 84-91. https://doi.org/10.1016/j.jclepro.2013.1 1.016

Kamil, F. N., Nurshazwani, Z. Z. W., Razali, T. M., Kian, S. T., and Zainal, N. (2020). Design of automated rubber tapping mechanism. International Conference on Technology, Engineering and Sciences (ICTES), 917, 012016.

Kang, G., Yan, D., Chen, X., Li, Y., Yang, L., and Zeng, R. (2020). Molecular characterization and functional analysis of a novel WRKY transcription factor HbWRKY83 possibly involved in rubber production of Hevea brasiliensis. Plant Physiology and Biochemistry, 155, 483-493. https://doi.org/10.1016/j.plaphy.2020.08 .013

Karunakaran, N., and Vijayan, J. V. P. (2020). Rubber production incentive scheme ( RPIS ) for cultivators and its effectiveness in Kasaragod district. Journal of Management Research and Analysis, $\quad 7(2), \quad 64-67$. https://doi.org/Original Research Article http://doi.org/10.18231/j.jmra.2020.014

Kim, Y., Li, S., Chekli, L., Woo, Y. C., Wei, C. H., Phuntsho, S., Ghaffour, N., Leiknes, T. O., and Shon, H. K. (2017). Assessing the removal of organic micro-pollutants from anaerobic membrane bioreactor effluent by fertilizer-drawn forward osmosis. Journal of Membrane Science, 533, 8495.

https://doi.org/10.1016/j.memsci.2017.0 3.027

Martinez-Hernandez, E., and Hernandez, J. E. (2018). Conceptualization, modeling and environmental impact assessment of a natural rubber techno-ecological system with nutrient, water and energy integration. Journal of Cleaner Production, 185, 707-722. https://doi.org/10.1016/j.jclepro.2018.0 2.297

MCI. (2019). (Ministry of Commerce and Industry). https://commerce.gov.in/InnerContent.a spx?type $=$ search $\& I d=1$

Md. Kamil, M. F., Nurshazwani Wan Zakaria, W., Razali Md Tomari, M., Kian Sek, T., and Zainal, N. (2020). Design of Automated Rubber Tapping Mechanism. IOP Conference Series: Materials Science and Engineering, 
917,

https://doi.org/10.1088/1757-

899x/917/1/012016

Najafpour, G. D., Zinatizadeh, A. A. L., Mohamed, A. R., Hasnain Isa, M., and Nasrollahzadeh, H. (2006). High-rate anaerobic digestion of palm oil mill effluent in an upflow anaerobic sludgefixed film bioreactor. Process Biochemistry, 41, 370-379. https://doi.org/10.1016/j.procbio.2005.0 6.031

Neves, L., Oliveira, R., and Alves, M. M. (2004). Influence of inoculum activity on the bio-methanization of a kitchen waste under different waste/inoculum ratios. Process Biochemistry, 39, 2019 2024

https://doi.org/10.1016/j.procbio.2003.1 0.002

Nguyen, H. N., and Luong, T. T. (2012). Situation of wastewater treatment of natural rubber latex processing in the Southeastern region, Vietnam. Journal of Vietnamese Environment, 2(2), 5864.

https://doi.org/10.13141/jve.vol2.no2.pp 58-64

Nhu Hien, N., Van Tuan, D., Nhat, P. T., Thi Thanh Van, T., Van Tam, N., Xuan Que, V. O. N., and Phuoc Dan, N. (2017). Application of Oxygen Limited Autotrophic Nitritation/Denitrification (OLAND) for anaerobic latex processing wastewater treatment. International Biodeterioration and Biodegradation, 124, 45-55. https://doi.org/10.1016/j.ibiod.2017.07. 009

Promnuan, K., Higuchi, T., Imai, T., Kongjan, P., Reungsang, A., and O-Thong, S. (2020). Simultaneous biohythane production and sulfate removal from rubber sheet wastewater by two-stage anaerobic digestion. International Journal of Hydrogen Energy, 45(1),
263-274.

https://doi.org/10.1016/j.ijhydene.2019. 10.237

Promnuan, K., and O-Thong, S. (2017). Biological Hydrogen Sulfide and Sulfate Removal from Rubber Smoked Sheet Wastewater for Enhanced Biogas Production. Energy Procedia, 138, 569574.

https://doi.org/10.1016/j.egypro.2017.1 0.161

Rahman, A., Habib, S., Rahman, M., Sajib, M. S. J., and Yousuf, A. (2019). A novel multi-phase treatment scheme for odorous rubber effluent. Environmental Technology (United Kingdom), O(0), 119.

https://doi.org/10.1080/09593330.2019. 1668965

Ramanan, G., and Vijayan, N. (2015). Treatment of Waste Water from Natural Rubber Processing Plant. International Journal of Scientific Engineering and Research, 4(7), 45-48. https://pdfs.semanticscholar.org/b45d/4 16d2c5a3ba57cd87ef5e130417ea7e420 07.pdf

Tanikawa, D., Kataoka, T., Hirakata, Y., and Hatamoto, M. (2020). Pre-treatment and post-treatment systems for enhancing natural rubber industrial wastewater treatment. Process Safety and Environmental Protection, 138, 256262.

https://doi.org/10.1016/j.psep.2020.03.0 30

Tanikawa, D., Kataoka, T., Sonaka, H., Hirakata, Y., and Hatamoto, M. (2020). Evaluation of key factors for residual rubber coagulation in natural rubber processing wastewater. Journal of Water Process Engineering, 33, 101041. https://doi.org/10.1016/j.jwpe.2019.101 041

Warren-Thomas, E., Dolman, P. M., and 
Edwards, D. P. (2015). Increasing Demand for Natural Rubber Necessitates a Robust Sustainability Initiative to Mitigate Impacts on Tropical Biodiversity. Conservation Letters, 8(4), 230-241. https://doi.org/10.1111/conl.12170

$\mathrm{Xu}$, F., Shi, J., Lv, W., Yu, Z., and Li, Y. (2013). Comparison of different liquid anaerobic digestion effluents as inocula and nitrogen sources for solid-state batch anaerobic digestion of corn stover. Waste Management, 33, 26-32. https://doi.org/10.1016/j.wasman.2012. 08.006

Young, B. J., Riera, N. I., Beily, M. E., Bres, P. A., Crespo, D. C., and Ronco, A. E. (2012). Toxicity of the effluent from an anaerobic bioreactor treating cereal residues on Lactuca sativa. Ecotoxicology and Environmental Safety, $\quad 76, \quad 182-186$. https://doi.org/10.1016/j.ecoenv.2011.0 9.019 .

\section{How to cite this article:}

Megha, A. S., P. Shaji James and Joejoe L. Bovas. 2020. Anaerobic Treatment of Rubber Latex Processing Effluent for Energy Production and Pollution Abatement. Int.J.Curr.Microbiol.App.Sci. 9(11): 1493-1503. doi: https://doi.org/10.20546/ijcmas.2020.911.177 